НАУКОВИЙ ВІСНИНК

Scientific messenger of Lviv National University

$\rightarrow$

(11)

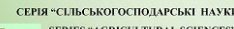

Том 22 № 93

2020
Науковий вісник Дьвівського національного університету ветеринарної медицини та біотехнологій імені С.3. Гжицького. Серія: Сільськогосподарські науки

Scientific Messenger of Lviv National University of Veterinary Medicine and Biotechnologies. Series: Agricultural sciences https://nvlvet.com.ua/index.php/agriculture

\title{
Analysis of the influence of genetic and non-genetic factors on the birth weight and weaning weight of lambs
}

\author{
A. S. Kramarenko, S. S. Kramarenko, S. I. Lugovoy, O. I. Yulevich \\ Mykolayiv National Agrarian University, Mykolayiv, Ukraine
}

Article info

Received 06.08.2020

Received in revised form 07.09 .2020

Accepted 08.09.2020

Mykolayiv National Agrarian University Georgiya Gongadze Str., 9, Mykolayiv, 54020, Ukraine. Tel.: +38-050-991-53-14 Email:kssnail0108@gmail.com
Kramarenko, A. S., Kramarenko, S. S., Lugovoy, S. I., \& Yulevich, O. I. (2020). Analysis of the influence of genetic and non-genetic factors on the birth weight and weaning weight of lambs. Scientific Messenger of Lviv National University of Veterinary Medicine and Biotechnologies. Series: Agricultural sciences, 22(93), 14-21. doi: 10.32718/nvlvet-a9303

The main aim of this paper is to analyze the influence of genetic and non-genetic factors on the birth weight and weaning weight of lambs. The study was carried out on the basis of the Institute of Animal Husbandry of Steppe Regions named by M. F. Ivanov "Askania-Nova" - the National Scientific Agricultural Center in Sheep Breeding of NAAS. Birth and weaning weights data collected during a 5-vear period from 3961 lambs were used. The reproductive traits of the Ascanian fine-fleece $(A C)$ ewes were evaluated in combination with the rams of different genotypes: Ascanian fine-fleece, Australian merino (AM) and halfbred animals $(1 / 2 A C+1 / 2 A M)$. The main effect of the ram genotype and the year of lambing, the age of the ewes, the litter size, the sex of lamb and the sex ratio in twins on the birth weight and weaning weight of lambs was analysed using one-way ANOVA. Differences between years of the 5-year period were highly significantly $(P<0.001)$ for all lamb traits studied. The effects of the environmental factor (year of lambing) on the birth weight and weaning weight of lambs represented 27.2 and 15.2 per cent of the total variance, respectively. The ram-group effects, which are mainly genetic differences, were highly significant $(P<0.001)$ in all traits. Age of dam had significant effect on the birth weight of lambs $(P=0.048)$ and was relatively unimportant as a source of variation. Two-year-old ewes bore lighter lambs than older ewes. There were no significant differences in the weaning weight of lambs from the ewes of different age classes. Survival rate was related to birth weight of lambs. Lamb survival increased up to a birth weight of $4.0 \mathrm{~kg}$ and only declined when they weighed more than $5.0 \mathrm{~kg}$ at birth. Our results showed that singles were $0.61 \mathrm{~kg}$ heavier than twins at birth and were $2.42 \mathrm{~kg}$ heavier than twins at weaning. Litter size (type of birth) was responsible for 42.5 and $10.0 \%$ of total variability in birth and weaning weights of lambs, respectively (in both cases: $P<0.001$ ). Average birth and weaning weights of male lambs were higher than the females (in both cases: $P<0.001$ ).

Key words: birth and weaning weight of lambs; ram genotype; year of lambing; age of the ewes; litter size (type of birth); sex of lamb; sex ratio in twins; the Ascanian fine-fleece breed.

\section{Аналіз впливу генетичних та не-генетичних факторів на живу масу ягнят при народженні та відлученні}

\author{
О. С. Крамаренко, С. С. Крамаренко, С. І. Луговий, О. І. Юлевич
}

Миколаївський наиіональний аграрний університет, м. Миколаїв, Украӥна

Основною метою роботи є аналіз впливу генетичних та не-генетичних факторів на живу масу ягнят при народженні та відлученні. Дослідження проведено на базі Інституту тваринництва степових районів ім. М. Ф. Іванова “Асканія-Нова" - Національного наукового селекиійно-генетичного чентру з вівчарства НААН України. Було використано дані щодо живої маси, отримані за 5-річний період від 3961 ягнят. Очінювалися відтворювальні якості вівцематок асканійської тонкорунної породи (АС) за їх поєднання з плідниками наступних генотипів: асканійська тонкорунна, австралійський меринос (АМ) та напівкровні тварини $(1 / 2 A C+1 / 2 A M)$. Вилив генотипу барана-плідника, а також року ягніння, віку вівиематок, розміру гнізда, статі ягняти та розподі- 
лу статей у двійнят було проаналізовано з використанням однофакторного дисперсійного аналізу. Було встановлено високо вірогідні відмінності $(P<0,001)$ між окремими роками за 5-річний період для всіх досліджених ознак ягнят. Вплив середовищного фактора (рік ягніння) на живу масу ягнят при народженні та відлученні обумовлював 27,2 та 15,2 \% загальної мінливості, відповідно. Вплив баранів-плідників, щуо відображує генотипові відмінності, був високо вірогідним (P < 0,001) для всіх ознак. Вік вівцематки впливав на живу масу ягнят при народженні $(P=0,048)$, але сила иього впливу була незначна. Дворічні вівцематки народжували ягнят с найменшою живою масою, ніж повновікові особини. Не було встановлено вірогідних відмінностей за живою масою ягнят при відлученні між вівцематками різних вікових груп. Збереженість була пов'язана із живою масою ягнят при народженні. Збереженість ягнят підвищувалася для тварин із масою до 4,0 кг при народженні, але різко знижувалася у тварин, щзо важили при народженні більше 5,0 кг. Отримані нами дані свідчать, щзо одинаки важили на 0,61 кг більще при народженні та на 2,42 кг при відлученні, ніж двійнята. Розмір гнізда (тип народження) обумовлював 42,5 та 10,0\% загальної мінливості живої маси ягнят при народженні та відлученні, відповідно (в обох випадках: $P$ < 0,001). Середня жива маса при народженні та відлученні баранців була вищчою, ніж ярок (в обох випадках: $P<0,001)$.

Ключові слова: жива маса ягнят при народженні та відлученні; генотип барана; рік ягніння; вік вівцематок; розмір гнізда (тип народження); стать ягняти; розподіл статей у двійнят; асканійська тонкорунна порода.

\section{Вступ}

Вівчарство в Україні історично завжди було невід'ємною частиною національного господарства, що забезпечує його потреби у специфічних видах сировини і продуктах харчування. Ця галузь являє собою джерело таких видів продукції як вовна, баранина, молоко, смушки, хутряні, шубні та шкіряні овчини, а також ланоліну та кишок для парфумерної і фармакологічної промисловості (Pokhyl \& Mykolaychuk, 2019). Але головною проблемою вівчарства залишається висока собівартість виробництва продукції. При тому, що вартість кормів, енергоносіїв, засобів механізації в Україні досягла світового рівня, а ціни на продукцію, які диктує сучасний ринок, становлять лише 30-40\% від світових (Vdovychenko \& Zharuk, 2019).

Вівчарство представлено в Україні найбільшою кількістю порід та порідних типів, хоча для даного виду тварин характерне суттєве скорочення чисельності вівцематок, причому, найбільш відчутно за період 2011-2019 років (Voitenko et al., 2019). Всього в Україні розводять близько 20-ти порід і типів овець різного напряму продуктивності, які пристосовані до іiі природно-кліматичних умов. Основна маса поголів'я належить до порід комбінованого - м'ясо-вовнового та вовново-м'ясного - напряму продуктивності (Vdovychenko \& Zharuk, 2019).

М'ясні якості молодняку овець пов'язані з великою кількістю чинників, основні 3 яких - це генотипові і паратипові фактори. Численними дослідженнями встановлено, що потомство, отримане в результаті промислового схрещування, відрізняється, як правило, більш високими кількісними показниками продуктивності (Pokhyl \& Mykolajchuk, 2020). 3 метою підвищення обсягів виробництва м'яса на тлі значної плодючості у вівчарстві застосовують промислове схрещування. В основі цього процесу покладено використання баранів-плідників інтенсивних порід, які вирізняються значним рівнем м'ясності. Помісні тварини, отримані від такого схрещування, за рахунок ефекту гетерозису, як правило, мають вищі показники м'ясності, ніж їх чистокровні аналоги, при цьому помісний молодняк росте інтенсивніше, а їх жива маса зазвичай на 3-10 \% більша (Pokhyl et al., 2020).

Успішне ведення вівчарства потребує наявності досконалої селекційної програми, що повинна враховувати вплив різноманітних факторів на всіх етапах технологічного процесу. При цьому, маса ягнят при народженні та відлученні відіграє важливу роль у підтриманні прибутковості галузі вівчарства як м'ясного, так і вовнового напрямку продуктивності (Petrović et al., 2015).

3 іншого боку, доведено, що на живу масу ягнят при народженні впливає велика кількість факторів генетичної та не-генетичної природи, включаючи, рік та сезон народження, вік вівцематки, номер окоту, розмір гнізда, стать ягняти та ін. (Vesely \& Peters, 1964; Eltawil et al., 1970; Mavrogenis, 1982; Burfening \& Kress, 1993; Yilmaz et al., 2007; Caro-Petrović et al., 2013; Sánchez-Dávila et al., 2015).

Крім того, на вівцях породи рамбульє було показано, що жива маса при народженні ягнят залежить від тривалості кітності - при ііі подовженні на одну добу середня жива маса новонароджених ягнят збільшувалася на 0,05 фунтів (тобто, 22,7 г) і, таким чином, відбір сприяв вівцематкам 3 більш пізнім ягнінням (Vesely \& Peters, 1964).

У цілому, жива маса при відлученні більшою мірою залежала від не-генетичних факторів, ніж маса при народженні. Це пов'язано із тим, що жива маса при відлученні залежить від таких факторів, як режим годівлі та молочність вівцематок. Водночас, жива маса при народженні зумовлюється виключно материнськими якостями вівцематок (Eltawil et al., 1970).

Отримані дані щодо продуктивності сільськогосподарських тварин (у тому числі, й овець) повинні бути скореговані на усунення (або зменшення) екологічних відмінностей між тваринами, для більш точного встановлення їх генетичних особливостей, які можна було б використовувати для складання ефективних планів розведення. Таким чином, необхідно враховувати вплив екологічних та фізіологічних джерел мінливості продуктивних ознак, таких як вік вівцематок, розмір гнізда (тип народження), рік дослідження, сезон року та інші характеристики середовища. Генетичні відмінності між тваринами існують, але суттевий вплив екологічних чинників ускладнює їх оцінку (Babar \& Javed, 2009).

Таким чином, основною метою роботи був аналіз впливу генетичних та не-генетичних факторів на живу масу ягнят при народженні та відлученні.

\section{Матеріал і методи досліджень}

Дослідження було проведено на базі Інституту тваринництва степових районів ім. М. Ф. Іванова 
“Асканія-Нова” - Національного наукового селекційно-генетичного центру з вівчарства НААН України.

Об'єктом дослідження був вплив генетичних та не-генетичних факторів на живу масу ягнят при народженні та відлученні.

В аналіз було включено дані щодо 2603 вівцематок, від яких було отримано 3961 ягнят протягом п’яти років дослідження.

Оцінювалися відтворювальні якості вівцематок асканійської тонкорунної породи (АС) за їх поєднання 3 плідниками наступних генотипів: асканійська тонкорунна, австралійський меринос (AM) та напівкровні тварини (1/2AC+1/2AM). Також було вивчено вплив року ягніння, віку вівцематок, розміру гнізда, статі ягнят та розподіл статей у двійнят (баран/баран, ярка/ярка, баран/ярка) на живу масу ягнят при народженні та відлученні.

Перевірку статистичної гіпотези щодо відсутності вірогідних відмінностей між груповими середніми було проведено за допомогою алгоритму однофакторного дисперсійного аналізу Р.Фішера, а перевірку статистичної гіпотези щодо відсутності вірогідних відмінностей між груповими варіансами - на підставі тесту Левене.

Для кожного фактора, що було досліджено, було розраховано коефіцієнт детермінації $\left(R^{2}\right)$, тобто, частку мінливості залежної ознаки, що обумовлено варіюванням певного фактора.

Всю статистичну обробку було проведено на підставі посібника S. Kramarenko et al. (2019) за допомогою програмного забезпечення MS Excel та PAST (Hammer et al., 2001).

\section{Результати та їх обговорення}

Встановлено, що рік ягніння суттєво впливав на живу масу ягнят як при народженні $(F(4 ; 3956)=289,43 ; \mathrm{P}<0,001)$, так й при відлученні $(F(4 ; 3609)=126,92 ; \mathrm{P}<0,001)$. При цьому, рівень варіабельності відповідних ознак також значно відрізнявся по роках (табл. 1). Вірогідний $(\mathrm{P}<0,01)$ вплив року ягніння на живу масу ягнят при відлученні раніше вже було відмічено при дослідженні вівцематок порід рамбульє (Vesely \& Peters, 1964) та Навахо (Navajo) (Eltawil et al., 1970).

\section{Таблиця 1}

Вплив року ягніння на живу масу ягнят при народженні та відлученні

\begin{tabular}{|c|c|c|c|c|c|c|}
\hline \multirow[t]{2}{*}{ Рік } & \multicolumn{3}{|c|}{ Жива маса при народженні, кг } & \multicolumn{3}{|c|}{ Жива маса при відлученні, кг } \\
\hline & $n$ & Mean & $S E$ & $n$ & Mean & $S E$ \\
\hline $\mathrm{I}$ & 720 & 4,16 & 0,03 & 639 & 25,35 & 0,19 \\
\hline II & 1060 & 4,52 & 0,02 & 962 & 30,02 & 0,19 \\
\hline III & 800 & 3,62 & 0,02 & 769 & 25,76 & 0,15 \\
\hline IV & 527 & 4,19 & 0,03 & 484 & 28,12 & 0,28 \\
\hline $\mathrm{V}$ & 854 & 4,24 & 0,02 & 760 & 25,40 & 0,19 \\
\hline$R^{2}$ & \multicolumn{3}{|c|}{0,272} & \multicolumn{3}{|c|}{0,152} \\
\hline Критерій Фішера & \multirow{2}{*}{\multicolumn{3}{|c|}{$\begin{array}{c}F(4 ; 3956)=289,43 ; \mathrm{P}<0,001 \\
F(4 ; 3956)=42,20 ; \mathrm{P}<0,001\end{array}$}} & \multirow{2}{*}{\multicolumn{3}{|c|}{$\begin{array}{c}F(4 ; 3609)=126,92 ; \mathrm{P}<0,001 \\
F(4 ; 3609)=30,69 ; \mathrm{P}<0,001\end{array}$}} \\
\hline Тест Левене & & & & & & \\
\hline
\end{tabular}

Високо вірогідні відмінності живої маси ягнят було виявлено при аналізі впливу генотипового фактора (при народженні: $F(2 ; 3958)=20,70 ;$ Р < 0,001; при відлученні: $F(2 ; 3611)=15,88 ;$ Р < 0,001), при цьому, найменших за живою масою ягнят було отримано від вівцематок, які ягнилися від баранів-плідників АМ або напівкровних баранів (табл. 2). Раніше вже було встановлено позитивний вплив баранів-плідників зарубіжної селекції (мериноладшаф та тексель) при спаровуванні їх з вівцематками асканійської тонкорунної породи на живу масу ягнят (Zaruba et al., 2019).

Рівень варіабельності між різними генотиповими групами вірогідно не відрізнявся стосовно живої маси при народженні, проте при відлученні оцінка мінливості ознаки була значно вищою у вівцематок, які були спаровані з баранами-плідниками АС.

У цілому, жива маса ягнят має суттєву генотипову компоненту - на вівцях породи Ромнелет (Romnelet) оцінка коефіцієнта успадкування живої маси при відлученні, отримана на підставі даних щодо продуктивності 694 пар “мати - дочка”, становила 0,28. Зі збільшенням віку ягнят ця оцінка також збільшувалася у однорічному віці вона становила вже 0,37 (Vesely \&
Slen, 1961). Для овець породи Chios оцінки коефіцієнта успадкування живої маси при народженні та відлученні становили 0,16 та 0,47, відповідно (Mavrogenis, 1982).

Для овець породи Chios рік ягніння не впливав на живу масу при народженні та при відлученні. При цьому, вірогідний вплив на дані ознаки було встановлено для фактора “плідник”, що був ієрархічно розподілений у межах фактора "рік ягніння" (Mavrogenis, 1982). Таким чином, можна припустити, що річні відмінності найчастіше маскуються генотиповою компонентою, оскільки в різні роки можуть використовуватися певні барани-плідники.

При цьому, вівцематки характеризуються відносною сталістю стосовно відношення живої маси при відлученні ягнят, що було ними народжено - оцінка коефіцієнта повторюваності даної ознаки для овець Навахо (Navajo) складала 0,22 (Sidwell \& Grandstaff, 1949).

При цьому, необхідно враховувати, що жива маса при відлученні має тісний кореляційний зв'язок із живою масою ягнят при народженні. В роботі (Eltawil et al., 1970) було показано, що введення корегуючої 
ко-варіанси (на масу ягнят при народженні) в модель при аналізі генотипової мінливості живої маси при відлученні суттєво знижувала вплив генетичної групи.

Нами було відмічено високо вірогідний $(\mathrm{P}<0,001)$ зв’язок між живою масою при народженні та відлу- ченні, але ступінь прояву цього зв'язку знижувалася в ряду $\mathrm{AC}(r=0,452 \pm 0,064 ; P<0,001) \rightarrow$ $1 / 2 \mathrm{AC}+1 / 2 \mathrm{AM}(r=0,379 \pm 0,023 ; P<0,001) \rightarrow \mathrm{AM}$ $(r=0,331 \pm 0,023 ; P<0,001)$.

\section{Таблиця 2}

Вплив генотипу барана-плідника на живу масу ягнят при народженні та відлученні

\begin{tabular}{|c|c|c|c|c|c|c|}
\hline \multirow[t]{2}{*}{ Генотип барана } & \multicolumn{3}{|c|}{ Жива маса при народженні, кг } & \multicolumn{3}{|c|}{ Жива маса при відлученні, кг } \\
\hline & $n$ & Mean & $S E$ & $n$ & Mean & $S E$ \\
\hline $\mathrm{AC}$ & 228 & 4,41 & 0,04 & 199 & 28,24 & 0,41 \\
\hline $1 / 2 \mathrm{AC}+1 / 2 \mathrm{AM}$ & 1865 & 4,18 & 0,02 & 1692 & 27,46 & 0,14 \\
\hline AM & 1868 & 4,12 & 0,01 & 1723 & 26,54 & 0,13 \\
\hline$R^{2}$ & \multicolumn{3}{|c|}{0,021} & \multicolumn{3}{|c|}{0,018} \\
\hline Критерій Фішера & \multirow{2}{*}{\multicolumn{3}{|c|}{$\begin{array}{c}F(2 ; 3958)=20,70 ; \mathrm{P}<0,001 \\
F(2 ; 3958)=1,17 ; \mathrm{P}>0,05\end{array}$}} & \multirow{2}{*}{\multicolumn{3}{|c|}{$\begin{array}{c}F(2 ; 3611)=15,88 ; \mathrm{P}<0,001 \\
F(2 ; 3611)=3,15 ; \mathrm{P}=0,043\end{array}$}} \\
\hline Тест Левене & & & & & & \\
\hline
\end{tabular}

Специфічні особливості процесів формування живої маси ягнят було отримано при розгляді вівцематок різних вікових груп. На живу масу при народженні вплив віку вівцематки був вірогідний $(F(6 ; 3954)=$ $2,12 ; \mathrm{P}=0,048)$, а також було встановлено вірогідні відмінності за рівнем варіабельності цієї ознаки (табл. 3). При цьому спостерігається поступове збільшення живої маси ягнят при народженні із зростанням віку вівцематки, із максимальним проявом ознаки у 7-річних тварин.

В роботі J. Vesely \& H. Peters (1964) на вівцях породи рамбульє було отримано аналогічні результати дворічні вівцематки народжували ягнят, що мали найменшу живу масу. Водночас, нащадків 3 найбіль- шою масою було отримано від вівцематок 6-7річного віку. Характерно, що до моменту відлучення різниця в живій масі ягнят, отриманих від вівцематок різного віку, нівелювалася.

У цілому, вік вівцематки більшою мірою впливав на живу масу ягнят при народженні та відлученні, ніж на живу масу в річному віці та характеристики вовнової продуктивності (Eltawil et al., 1970). В цілому, R. Blackwell \& C. Henderson (1955) встановили, що жива маса ягнят при народженні збільшувалася на 0,317 кг на кожний додатковий рік збільшення віку вівцематок. Стосовно живої маси при відлученні вони відмічали наявність квадратичної регресії із максимумом, що достягається вівцематками 5-річного віку.

Таблиця 3

Вплив віку вівцематки на живу масу ягнят при народженні та відлученні

\begin{tabular}{|c|c|c|c|c|c|c|}
\hline \multirow{2}{*}{ Вік, роки } & \multicolumn{3}{|c|}{ Жива маса при народженні, кг } & \multicolumn{3}{|c|}{ Жива маса при відлученні, кг } \\
\hline & $n$ & Mean & $S E$ & $n$ & Mean & $S E$ \\
\hline 2 & 365 & 4,06 & 0,03 & 334 & 26,61 & 0,30 \\
\hline 3 & 994 & 4,18 & 0,02 & 909 & 27,07 & 0,19 \\
\hline 4 & 926 & 4,17 & 0,02 & 844 & 27,20 & 0,19 \\
\hline 5 & 688 & 4,17 & 0,02 & 634 & 27,16 & 0,22 \\
\hline 6 & 493 & 4,17 & 0,03 & 449 & 27,47 & 0,28 \\
\hline 7 & 331 & 4,23 & 0,04 & 299 & 26,69 & 0,35 \\
\hline $8+$ & 164 & 4,16 & 0,05 & 145 & 26,38 & 0,40 \\
\hline$R^{2}$ & \multicolumn{3}{|c|}{0,002} & \multicolumn{3}{|c|}{0,001} \\
\hline Критерій Фішера & \multicolumn{3}{|c|}{$F(6 ; 3954)=2,12 ; \mathrm{P}=0,048$} & \multicolumn{3}{|c|}{$F(6 ; 3607)=1,42 ; \mathrm{P}>0,05$} \\
\hline Тест Левене & \multicolumn{3}{|c|}{$F(6 ; 3954)=3,78 ; \mathrm{P}<0,001$} & \multicolumn{3}{|c|}{$F(6 ; 3607)=2,05 ; \mathrm{P}>0,05$} \\
\hline
\end{tabular}

Аналогічні результати було отримано й у нашому дослідженні - при відлученні жива маса ягнят, які народилися від різновікових вівцематок була майже на одному рівні й вірогідно не відрізнялася $(F(6 ; 3607)$ $=1,42 ; \mathrm{P}>0,05)$. Аналогічно, майже на одному рівні був і рівень варіабельності даної ознаки у ягнят різних груп (табл. 3).

Характерно, що відмічалося поступове збільшення живої маси при відлученні зі збільшенням віку вівцематок з 2-х до 6-ти років, але для найбільш дорослих тварин цей показник різко зменшувався, аналогічно результатам, отриманим раніше в дослідженні (Vesely $\&$ Peters, 1964). Вівцематки віком 8+ років характери- зуються відносно низькою молочністю, що призводить до зменшення живої маси при відлученні отриманих від них ягнят, проте найбільші за живою масою ягнята були отримані від вівцематок 4-7-річного віку, що пов'язано з їх високою молочністю (Eltawil et al., 1970).

Характерно, що між живою масою ягнят при народженні та їх збереженістю було виявлено криволінійний зв'язок (рис. 1). Особини із найбільшою та найменшою живою масою при народженні мали на 4-7 \% збереженість нижче, ніж ягнята, які народилися із живою масою близькою до оптимуму (4-5 кг). Аналогічні результати було раніше отримано в дослідженні 
чистопородних та напівкровних ягнят породи ромнімарш (Romney), в яких найвищу збереженість відмі- чено серед особин, що народилися із живою масою 912 фунтів, тобто, 4,1-5,4 кг (Hight \& Jury, 1970).

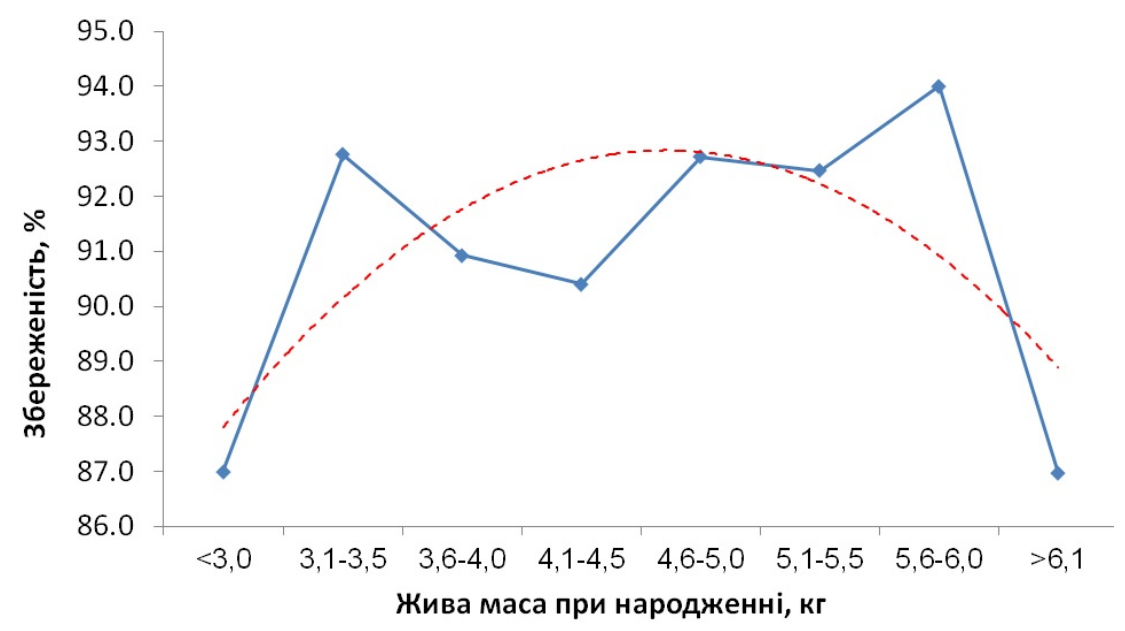

Рис. 1. Залежність збереженості ягнят від їх живої маси при народженні.

(Наведено лінію тренду за поліномом другого ступеня)

Як можна було очікувати, розмір гнізда суттєво впливав на живу масу ягнят як при народженні $(F(2 ; 3956)=595,28 ; \mathrm{P}<0,001)$, так і при відлученні $(F(2 ; 3609)=73,72 ; \mathrm{P}<0,001)$. При цьому, зі збільшенням кількості ягнят у гнізді зменшувалася їх жива маса, але значно зростав рівень варіабельності ознак (табл. 4).

\section{Таблиця 4}

Вплив розміру гнізда на живу масу ягнят при народженні та відлученні

\begin{tabular}{ccccccc}
\hline Кількість ягнят в & \multicolumn{3}{c}{ Жива маса при народженні, кг } & \multicolumn{2}{c}{ Жива маса при відлученні, кг } \\
\cline { 2 - 6 } гнізді & $n$ & Mean & $S E$ & $n$ & Mean \\
\hline одне & 1197 & 4,61 & 0,02 & 1083 & 28,77 & 0,18 \\
два & 2658 & 4,00 & 0,01 & 2430 & 26,35 & 0,11 \\
три & 104 & 3,28 & 0,05 & 99 & 25,77 & 0,51 \\
\hline$R^{2}$ & 0,425 & & $F(2 ; 3609)=73,72 ; \mathrm{P}<0,001$ \\
\hline Критерій Фішера & \multicolumn{7}{c}{$F(2 ; 3956)=595,28 ; \mathrm{P}<0,001$} & $F(2 ; 3609)=8,83 ; \mathrm{P}<0,001$ \\
Тест Левене & $F(2 ; 3956)=14,80 ; \mathrm{P}<0,001$ &
\end{tabular}

Різниця між живою масою при народженні баранців та ярок породи рамбульє складала 0,6 фунтів, тобто, біля 272 г, а різниця між ягнятами-одинаками та двійнятами - 2,0 фунти, тобто, біля 907 г (Vesely \& Peters, 1964). В умовах аридного клімату різниця між живою масою при народженні ягнят-одинаків та двійнят більш важлива в умовах пасовищного утримання

овець, ніж при утриманні на фермах (Eltawil et al., 1970). Крім того, ці автори також вказували, що суттєва частина мінливості між одинаками та двійнятами за живою масою при відлученні пов'язана переважно iз різницею в їх живій масі при народженні, ніж із кількістю ягнят у гнізді.

\section{Таблиця 5}

Вплив статі на живу масу ягнят при народженні та відлученні

\begin{tabular}{|c|c|c|c|c|c|c|}
\hline \multirow{2}{*}{ Стать ягнят } & \multicolumn{3}{|c|}{ Жива маса при народженні, кг } & \multicolumn{3}{|c|}{ Жива маса при відлученні, кг } \\
\hline & $n$ & Mean & $S E$ & $n$ & Mean & $S E$ \\
\hline баран & 1972 & 4,25 & 0,01 & 1779 & 27,72 & 0,14 \\
\hline ярка & 1989 & 4,08 & 0,01 & 1835 & 26,42 & 0,13 \\
\hline$R^{2}$ & \multicolumn{3}{|c|}{0,032} & \multicolumn{3}{|c|}{0,026} \\
\hline Критерій Фішера & \multicolumn{3}{|c|}{$F(1 ; 3959)=65,63 ; P<0,001$} & \multicolumn{3}{|c|}{$F(1 ; 3612)=48,62 ; P<0,001$} \\
\hline Тест Левене & \multicolumn{3}{|c|}{$F(1 ; 3959)=3,68 ; P>0,05$} & \multicolumn{3}{|c|}{$F(1 ; 3612)=13,92 ; P<0,001$} \\
\hline $\begin{array}{l}\text { Критерій Хі-квадрат } \\
\text { Пірсона }(1: 1)\end{array}$ & \multicolumn{3}{|c|}{$\chi^{2}=0,07 ; d f=1 ; P>0,05$} & \multicolumn{3}{|c|}{$\chi^{2}=0,87 ; d f=1 ; P>0,05$} \\
\hline
\end{tabular}


Співвідношення статей вірогідно не відхилялися від рівномірного ані при народженні (критерій $\mathrm{Xi}$ квадрат Пірсона: $\left.\chi^{2}=0,07 ; d f=1 ; \mathrm{P}>0,05\right)$, ані при відлученні $\left(\chi^{2}=0,87 ; d f=1 ; \mathrm{P}>0,05\right)$.

Серед ягнят, які народилися від вівцематок дніпропетровського типу асканійської м'ясо-вовнової породи, було відмічено переважання ярок при народжені, але статевий розподіл також вірогідно не відхилявся від рівномірного (Vovchenko \& Klyuyenkov, 2012). Але в роботі (Nezhlukchenko \& Oboista, 2013) було показано, що серед вівцематок, які ягнилися від баранів таврійського типу асканійської тонкорунної породи, характерно народження більшої чисельності ярок у багатоплідних окотах, хоча знову ж вірогідного відхилення від рівномірної статевої структури не доведено.

Також нами не було встановлено вірогідного відхилення від рівномірного $(1: 2: 1)$ і стосовно типу двійні ані при народженні $\left(\chi^{2}=2,45 ; d f=2 ; \mathrm{P}>0,05\right)$, ані при відлученні $\left(\chi^{2}=1,53 ; d f=2 ; \mathrm{P}>0,05\right)$.

Співвідношення статей серед двійнят вірогідно впливало на живу масу ягнят при народженні $(F(2 ; 2655)=5,35 ; \mathrm{P}=0,005)$ та при відлученні $(F(2$; $2427)=9,29 ; \mathrm{P}<0,001)$. При цьому, найбільшу живу масу було зафіксовано серед ягнят, які народилися у парах баран/баран, а найменшу - у парах ярка/ярка (табл. 6). Хоча значних коливань ознак встановлено не було серед тварин із двійневих окотів різних типів.

\section{Таблиця 6}

Вплив співвідношення статей серед двійнят на живу масу ягнят при народженні та відлученні

\begin{tabular}{|c|c|c|c|c|c|c|}
\hline \multirow{2}{*}{$\begin{array}{c}\text { Співвідношення ста- } \\
\text { тей }\end{array}$} & \multicolumn{3}{|c|}{ Жива маса при народженні, кг } & \multicolumn{3}{|c|}{ Жива маса при відлученні, кг } \\
\hline & $n$ & Mean & $S E$ & $n$ & Mean & $S E$ \\
\hline баран/баран & 635 & 4,05 & 0,02 & 585 & 26,95 & 0,23 \\
\hline баран/ярка & 1331 & 4,00 & 0,01 & 1217 & 26,43 & 0,15 \\
\hline ярка/ярка & 692 & 3,96 & 0,02 & 628 & 25,64 & 0,21 \\
\hline$R^{2}$ & \multicolumn{3}{|c|}{0,005} & \multicolumn{3}{|c|}{0,011} \\
\hline Критерій Фішера & \multirow{2}{*}{\multicolumn{3}{|c|}{$F(2 ; 2655)=5,35 ; P=0,005$}} & \multicolumn{3}{|c|}{$F(2 ; 2427)=9,29 ; P<0,001$} \\
\hline Тест Левене & \multicolumn{2}{|c|}{$F(2 ; 2655)=0,66 ; P>0,05$} & & \multicolumn{3}{|c|}{$F(2 ; 2427)=0,45 ; P>0,05$} \\
\hline $\begin{array}{l}\text { Критерій Хі-квадрат } \\
\text { Пірсона }(1: 2: 1)\end{array}$ & \multicolumn{3}{|c|}{$\chi^{2}=2,45 ; d f=2 ; P>0,05$} & \multicolumn{3}{|c|}{$\chi^{2}=1,53 ; d f=2 ; P>0,05$} \\
\hline
\end{tabular}

3 іншого боку, саме із ярок, що було народжено із одностатевих двієнь у вівцематок таврійського типу асканійської тонкорунної породи, рекомендується комплектувати ремонтне поголів'я, оскільки вони характеризувалися кращою відтворювальною здатністю (Besedin, 2011).

В цілому, ягнята, що мали найбільшу живу масу при народженні (через те, що вони були або баранчиками, або народжені одинаками, або народжені від повновікових вівцематок), мали тенденцію досягати більшої живої маси при відлученні частково завдяки суттєвої кореляції між цими двома ознаками, що раніше вже було відмічено (Eltawil et al., 1970). Коефіцієнт регресії живої маси при відлученні від живої маси при народженні для досліджених тварин становив $3,20 \pm 0,14$. Він був дещо вищим, ніж оцінка $2,45 \pm$ 0,11 , що була отримана в дослідженні E. Eltawil et al. (1970) та знаходилася в інтервалі значень 2,50-5,96, що було отримано в дослідженні R. De Baca et al. (1956).

Оцінка коефіцієнта генетичної кореляції між живою масою при народженні та відлученні звичайно має позитивне та високе значення, так в дослідженні A. Mavrogenis (1982) для овець породи Chios воно досягало рівня $+0,82$.

В цілому, сила впливу фактору $\left(R^{2}\right)$ була найвищою для розміру гнізда $(0,100-0,425)$ та року ягніння $(0,152-0,272)$, причому в обох випадках вплив фактора на живу масу ягнят при народженні був вищим, ніж при відлученні (табл. 1-6).

\section{Висновки}

1. Встановлено високо вірогідні відмінності $(\mathrm{P}<0,001)$ між окремими роками за 5-річний період для всіх досліджених ознак ягнят. Вплив середовищного фактора (рік ягніння) на живу масу ягнят при народженні та відлученні обумовлював 27,2 та 15,2 \% загальної мінливості, відповідно.

2. Вплив баранів-плідників, що відображує генотипові відмінності, був високо вірогідним $(\mathrm{P}<0,001)$ для всіх ознак.

3. Вік вівцематки впливав на живу масу ягнят при народженні $(\mathrm{P}=0,048)$, але сила цього впливу була незначна. Дворічні вівцематки народжували ягнят 3 найменшою живою масою, ніж повновікові особини. Не було встановлено вірогідних відмінностей за живою масою ягнят при відлученні між вівцематками різних вікових груп.

4. Збереженість була пов'язана із живою масою ягнят при народженні. Збереженість ягнят підвищувалася для тварин із масою до 4,0 кг при народженні, але різко знижувалася у тварин, що важили при народженні більше 5,0 кг.

5. Отримані нами дані свідчать, що одинаки важили на 0,61 кг більше при народженні та на 2,42 кг при відлученні, ніж двійнята. Розмір гнізда (тип народження) обумовлював 42,5 та 10,0 \% загальної мінливості живої маси ягнят при народженні та відлученні, відповідно (в обох випадках: Р <0,001).

6. Середня жива маса при народженні та відлученні баранців була вищою, ніж ярок (в обох випадках: $\mathrm{P}<0,001)$. 
Перспективи подальиих досліджень. Наше дослідження показало, що серед низки факторів генетичної та не-генетичної природи, на живу масу ягнят при народженні та відлученні найбільший вплив мали рік ягніння та розмір гнізда (тип народження). Таким чином, наступним етапом буде аналіз взаємодії різних факторів i, насамперед, аналіз взаємодії “генотип $\times$ середовище".

Подяки. Робота виконана в рамках фінансування за держбюджетною тематикою Міністерства освіти і науки України (номер державної реєстрації 0119U001042).

\section{References}

Babar, M. E., \& Javed, K. (2009). Non-genetic factors affecting reproductive traits in Lohi sheep. Acta Agriculturae Scandinavica, Section A - Animal Science, 59(1), 48-52. doi: 10.1080/09064700802650035.

Besedin, O. (2011). Features of reproductive ability of ewes of Taurian type of Ascanian Merino breed. Premountain and Mountain Agriculture and Stockbreeding, 53(I), 108-112 (in Ukrainian).

Blackwell, R. L., \& Henderson, C. R. (1955). Variation in fleece weight, weaning weight and birth weight of sheep under farm conditions. Journal of Animal Science, 14(3), 831-843. doi: 10.2527/1955.143831x.

Burfening, P. J., \& Kress, D. D. (1993). Direct and maternal effects on birth and weaning weight in sheep. Small Ruminant Research, 10(2), 153-163. doi: 10.1016/0921-4488(93)90058-P.

Caro-Petrović, V., Petrović, M. P., Ilić, Z., Petrović, M. M., Milošević, B., Ružić-Muslić, D., \& Maksimović, N. (2013). Effect of genotype, sire, sex, gestation length on birth weight of lambs. Biotechnology in Animal Husbandry, 29(4), 685-693. doi: 10.2298/BAH1304685C.

DeBaca, R. C., Bogart, R., Calvin, L. D., \& Nelson, O. M. (1956). Factors affecting weaning weights of crossbred spring lambs. Journal of Animal Science, 15(3), 667-678. doi: 10.2527/jas1956.153667x.

Eltawil, E. A., Hazel, L. N., Sidwell, G. M., \& Terrill, C. E. (1970). Evaluation of environmental factors affecting birth, weaning and yearling traits in Navajo sheep. Journal of Animal Science, 31(5), 823-827. doi: $10.2527 /$ jas $1970.315823 x$.

Hammer, Ø., Harper, D. A., \& Ryan, P. D. (2001). PAST: Paleontological Statistics Software Package for Education and Data Analysis. Palaeontologia Electronica, 4, 1-9. http://palaeo-electronica.org/2001_1/past/issue1_01.htm.

Hight, G. K., \& Jury, K. E. (1970). Hill country sheep production: II. Lamb mortality and birth weights in Romney and Border Leicester $\times$ Romney flocks. New Zealand Journal of Agricultural Research, 13(4), 735752. doi: 10.1080/00288233.1970.10430507.

Kramarenko, S. S., Lugovy, S. I., Lykhach, A. V. \& Kramarenko, O. S. (2019). Analysis of biometric data in animal breeding and selection. Mykolayiv, MNAU. 211 (in Ukrainian).

Mavrogenis, A. P. (1982). Environmental and genetic factors influencing milk production and lamb output of Chios sheep. Livestock Production Science, 8(6), 519-527. doi: 10.1016/0301-6226(82)90029-X.

Nezhlukchenko, T. I., \& Oboista, T. V. (2013). Intrabreed features of the reproductive capacity of Askanian finefleece sheep. Taurida Scientific Herald. Series: Rural Sciences, 83, 188-191 (in Ukrainian).

Petrović, M. P., Caro Petrović, V., Ružić-Muslić, D., Maksimović, N., Petrović, M. M., Ilić, Z.Z., \& Stojković, J. (2015). Effect of genetic and environmental factors on the phenotype characteristics of lambs. Biotechnology in Animal Husbandry, 31(2), 223-233. doi: 10.2298/BAH1502223P.

Pokhyl, V. I., \& Mykolaychuk, L. P. (2019). Age-related variability of the woollen coat of Romanivska sheep breed. Theoretical and Applied Veterinary Medicine, 7(3), 172-176. doi: 10.32819/2019.71031 (in Ukrainian).

Pokhyl, V. I., \& Mykolajchuk, L. P. (2020). Meat productivity of young sheep animals of different origin. Theoretical and Applied Veterinary Medicine, 8(1), 2630. doi: 10.32819/2020.81005(in Ukrainian).

Pokhyl, V. I., Mykolajchuk, L. P., \& Izhboldina, O. O. (2020). Features of sheepskin productivity of different origin sheep. Theoretical and Applied Veterinary Medicine, 8(2), 128-131. doi: 10.32819/2020.82017 (in Ukrainian).

Sánchez-Dávila, F., Bernal-Barragán, H., Padilla-Rivas, G., del Bosque-González, A. S., Vázquez-Armijo, J. F., \& Ledezma-Torres, R. A. (2015). Environmental factors and ram influence litter size, birth, and weaning weight in Saint Croix hair sheep under semi-arid conditions in Mexico. Tropical Animal Health and Production, 47(5), 825-831. doi: 10.1007/s11250-0150795-6.

Sidwell, G. M., \& Grandstaff, J. O. (1949). Size of lambs at weaning as a permanent characteristic of Navajo ewes. Journal of Animal Science, 8(3), 373-380. doi: $10.2527 /$ jas $1949.83373 x$.

Vdovychenko, Yu., \& Zharuk, P. (2019). Genetic resources of sheep in Ukraine. Bulletin of Agricultural Science, 97(5), 38-44. doi: 10.31073/agrovisnyk201905-04 (in Ukrainian).

Vesely, J. A., \& Peters, H. F. (1964). The effects of breed and certain environmental factors on birth and weaning traits of range sheep. Canadian Journal of Animal Science, 44(2), 215-219. doi: 10.4141/cjas64-033.

Vesely, J. A., \& Slen, S. B. (1961). Heritabilities of weaning weight, yearling weight, and clean fleece weight in range romnelet sheep. Canadian Journal of Animal Science, 41(1), 109-114. doi: 10.4141/cjas61-014.

Voitenko, S. L., Porkhun, M. G., Sydorenko, O. V., \& Ilnytska, T. Y. (2019). Genetic resources of agricultural animals of Ukraine at the beginning of the third millennium. Animal Breeding and Genetics, 58, 110 119. doi: 10.31073/abg.58.15 (in Ukrainian).

Vovchenko, B. O., \& Klyuyenkov, V. O. (2012). The evaluation of breeding and productive characters of ewes of the Dnipropetrovs'k type of Askanian mutton and wool sheep. Taurida Scientific Herald. Series: Rural Sciences, 78, 2(1), 38-41 (in Ukrainian). 
Yilmaz, O., Denk, H., \& Bayram, D. (2007). Effects of lambing season, sex and birth type on growth performance in Norduz lambs. Small Ruminant Research, 68(3), 336-339. doi: 10.1016/j.smallrumres.2005.11.013.

Zaruba, K. V., Drozd, S. L., \& Gladii, I. A. (2019). The results of crossbreeding the rams-sires foreign breed- ing with the ewes of the Ascanian fine-fleeced breed. Sheep and Goat Breeding, 4, 34-42. doi: 10.33694/2415-3958-2019-1-4-34-42 (in Ukrainian). 